\title{
Relationship between intangible resources, absorptive capacities and export performance
}

\author{
Relação entre recursos intangíveis, capacidades absortivas e desempenho das exportações
}

\author{
Alexandra França \\ University of Vigo, 36310 Vigo, Spain, franca.alexandra@gmail.com \\ Orlando Lima Rua \\ Polytechnic of Porto/ISCAP/CEOS.PP; APNOR/UNIAG, 4200-465 Porto, Portugal, orua@iscap.ipp.pt
}

\begin{abstract}
The new paradigm of today's world economy is characterized by the mobility of production resources and the ability to combine them in an efficient way. The strategic management research has recognized the importance of studying the companies' resources and capabilities and its usefulness to achieve competitive advantage. This perspective is consistent with the Resource-Based View (RBV) and with the Dynamic Capabilities View (DCV). The source of competitive advantage is much more correlated with intangible resources, since these are rarer and socially complex, making their imitation difficult. Consequently, intangible resources are considered strategic resources, since it allows creating perceived value by the customer, outperforming the competition, competing in new markets and being use in a wide range of products and services. On the other hand, the processes for absorbing external knowledge became an essential element for firms to adapt to changes in the competitive environment. Thus knowledge plays an important role in firms' internationalization process.
\end{abstract}

Building on well-established theories, our research explores the influence of intangible resources and absorptive capacities in export performance of Portuguese small and medium enterprises (SMEs) of footwear associated to the Portuguese Footwear, Components and Leather Goods Association (APICCAPS). Based on survey data from 42 firms, our empirical results indicate that globally intangible resources and absorptive capacity have a positive and significant influence on export performance. On one hand, the intangible resources that most contribute to this end are reputational resources, access to financial resources and relational resources, and on the other hand the absorptive capacities that most contribute to export performance are exploitation of knowledge, transformation of knowledge and general knowledge acquisition.

Keywords: Intangible resources, absorptive capacities, export performance, SMEs, Portuguese footwear industry, PLS-SEM.

\section{Resumo}

O novo paradigma da atualidade da economia mundial carateriza-se pela mobilidade dos recursos produtivos e pela capacidade de combinálos de forma eficiente. A investigação em gestão estratégica tem reconhecido a importância do estudo dos recursos e capacidades das empresas, bem como a sua utilidade para alcançar vantagem competitiva. Esta perspetiva é consistente com a Resource-Based View (RBV) e com a Dynamic Capabilities View (DCV). A fonte de vantagem competitiva surge mais correlacionada com recursos intangíveis, dado estes serem raros e socialmente complexos, dificultando a sua imitação. Consequentemente, os recursos intangíveis são considerados estratégicos, uma vez que permitem criar valor percebido pelo cliente, superar a concorrência e competir em novos mercados, sendo utilizados numa ampla gama de produtos e serviços. Por outro lado, os processos para absorção de conhecimento externo tornaram-se um elemento essencial para as empresas se adaptarem às mudanças no ambiente competitivo. O conhecimento desempenha assim um papel importante no processo de internacionalização das empresas.

Baseada em teorias bem estabelecidas, a presente investigação explora a influência dos recursos intangíveis e das capacidades absortivas no desempenho das exportações de pequenas e médias empresas (PME) membros da Associação Portuguesa dos Industriais de Calçado, Componentes a Artigos de Pele e seus Sucedâneos (APICCAPS). Com base numa amostra de 42 empresas, os resultados empíricos deste estudo indicam que os recursos intangíveis e as capacidades absortivas têm uma influência positiva e significativa no desempenho das exportações. Por um lado, os recursos intangíveis que mais contribuem para o efeito são os recursos reputacionais, o acesso a recursos financeiros e os recursos relacionais, e, por outro, as capacidades absortivas que mais contribuem para o desempenho das exportações são a exploração do conhecimento, a transformação do conhecimento e a aquisição de conhecimentos gerais.

Palavras chave: Recursos intangíveis, capacidades absortivas, desempenho das exportações, PME, indústria portuguesa do calçado, PLS-MEE.

\section{Introduction}

Competition in the global economy of 21st century is complex, demanding, and filled with opportunities and threats (Ireland \& Hitt, 2005). The intensity of business competition has increased considerably, forcing organizations to seek and adopt new management perspectives and techniques. Developing and maintaining competitive advantage is a dynamic and neverending activity (Hung, Yang \& Lien, 2010).

In a dynamic and turbulent environment, knowledge represents a critical resource to create value and to develop and sustain competitive advantages (Teece, Pisano \& Shuen, 1997). However, fast changing environments, technologies and

competitiveness intensify the challenges firms face in attaining self-sufficiency in knowledge creation (Camisón \& Forés, 2010).

Several strategic management scholars argue that ResourceBased View (RBV) has basically "in-ward" orientation. Although RBV recognizes that "the value of the firm's resources and capabilities is determined by the market context within which the firm is operating" (Barney, 2001, p. 645), it does not address the processes of converting resources and capabilities into customer value (Möller, 2006).

A second body of literature in the field of strategic management has focused on dynamic capabilities (for a review see Barreto, 2010). The firms' success depends not only on its' resources and capabilities, but also the ability to adapt itself to the industry 
contingencies and the markets in which operates. Firms may possess resources but must display dynamic capabilities otherwise shareholder value will be destroyed (Bowman \& Ambrosini, 2003). It is in this context that emerges the Dynamic Capabilities View (DCV) (Amit \& Schoemaker, 1993; Teece et al., 1997) to support the adjustment to environmental change. Dynamic capabilities as a mind-set constantly integrate, reconfigure, renew and recreate its core capabilities in response to the ever changing environment in order to achieve and sustain competitive advantage (Wang \& Ahmed, 2007). Moreover, these capabilities sense and shape opportunities and threats, seize opportunities, and maintain competitiveness by enhancing, combining, protecting, and reconfiguring the businesses' intangible and tangible resources (Teece, 2007).

DCV is not divergent but rather an important stream of RBV to gain competitive advantage in increasingly demanding environments (Ambrosini \& Bowman, 2009; Barreto, 2010; Eisenhardt \& Martin, 2000; Wang \& Ahmed, 2007). Monteiro, Soares and Rua (forthcoming) defend that in versatile markets the firms' capabilities should be dynamic and managers must display the ability to ensure consistency between the business environment and strategy in order to continuously renew skills.

Absorptive capacity (AC) has become one of the most significant constructs in the last twenty years and it is the dynamic capability that allows firms to gain and sustain a competitive advantage through the management of the external knowledge (Camisón \& Forés, 2010). Literature increasingly recognizes that competitive advantages no longer rely on internal knowledge alone, but rather derive from absorbing external knowledge (Gebauer, Worch, \& Truffer, 2012).

Studies within the strategic management literature have highlighted the important role of AC in achieving higher firm performance. Indeed, absorptive capacity is a mean of attaining superior financial performance, and transforming external knowledge inflows into performance gains (Kostopoulos, Papalexandris, Papachroni \& loannou, 2011).

As the importance of internationalization grows for many firms around the globe, there is an increasing interest in the strategic determinants that predict export performance. Therefore, research on export performance has developed exponentially. This increase interest of the academia was originated from the various macro and micro-level benefits associated with export development. At the macro-level, superior export performance is a cost-effective vehicle for economic growth, employment creation and a general improvement in the standards of living. There are countless benefits at the firm-level including opportunities for growth, larger market shares, better margins and diversification of risk (Kahiya \& Dean, 2014).

Thus, our research aims at exploring the influence of intangible resources and absorptive capacity in export performance of Portuguese SMEs exporting footwear. In the years before the economic crisis, Portugal had low growth and a decline in export competitiveness. Strengthening its export performance was and still is one of the principal challenges. Given that exporting firms are typically the top performers in Portuguese industry (Arnold, 2015), it is important to study firms that are participating in international trade. Changes in the export structure have occurred in some sectors, for example in textiles and footwear, where Portugal's exports have moved into higher value-added products (Arnold, 2015). The Portuguese footwear industry had in the last years a remarkable performance in the exportation values and others economic indicators. After a long period of difficulties, the Portuguese footwear industry changed the strategy and is now a success case among the international players of footwear (Marques \& Guedes, 2015).

\section{Literature review}

\subsection{Intangible resources}

Resources and capabilities are a set of tangible and intangible assets that can be used by firms to help choose and implement strategies (Barney, Ketchen \& Wright, 2011). There is a consensus in the literature that the sources of competitive advantage are more associated to intangible resources than with the tangible ones. In addition, the tangible assets tend to depreciate over the time, while intangible assets may accumulate value over time (Porter, 1991).

Scholars argue that resources form the basis of firm strategies (Barney, 1991). Therefore, firm resources and strategy cooperate to create positive returns. Firms employ both tangible resources (such as physical infrastructures and financial resources) and intangible resources (like knowledge and brand equity) in the development and implementation of strategies. However, intangible resources are more likely than tangible resources to produce a competitive advantage, since they are often rare and socially complex, thereby making them difficult to imitate (Hitt, Bierman, Shimizu \& Kochhar, 2001). Thus, intangible resources are considered strategic resources (Amit \& Schoemaker, 1993).

Intangibles resources have three intrinsic characteristics that distinguish them from tangible resources (Molloy, Chadwick, Ployhart \& Golden, 2011). First, intangibles do not deteriorate with use, since these resources are expected to confer benefits for an indeterminate period of time (Cohen, 2005). Secondly, multiple managers can use the intangibles resources simultaneously, for example, the use of a brand is available for all managers. Finally, the intangibles resources are immaterial, making them difficult to exchange, as they often cannot be separated from its' owner (Marr \& Roos, 2005).

The existing literature suggests six types of resources that are particularly important sources of export venture competitive advantage: reputational resources; access to financial resources; human resources; cultural resources; relational resources; and, informational resources (Morgan, Vorhies \& Schlegelmilch, 2006).

The RBV describes reputation as an intangible resource that is consequent from combinations of internal investments and 
external evaluations (Shamsie, 2003). This "social approval assets" (Pfarrer, Pollock \& Rindova, 2010) can positively impact customer behaviour (Gatzert, 2015), loyalty and consumption experience (Cretu \& Brodie, 2007). Reputational resources concern intangible image-based assets available to firms and can be a differentiation factor in the target market (Hall, 1992). These resources must be understood as a source of competitive advantage, since they are rare, difficult to imitate and transfer and permeate the company's activity (Barney, 1991). This valuable intangible resource allows firms to build and protect their market share, enhance marketing investments and introduce new products in the export target market more easily (Aaker, 2010).

Access to financial resources allows a firm to pursue a broader range of activities as well as more ambitious projects. Financial resources can be invested into capital-intensive projects that may enable firms to secure existing markets as well as enter new ones (Westhead, Wright \& Ucbasaran, 2001). Therefore, financial capital is an important resource and it is not so much the ownership of the resource that is important but the access to it (Wiklund \& Shepherd, 2005). Firms with financial resources tend to respond more rapidly to market changes and to obtain competitive advantage more easily (Chesbrough \& Teece, 2002).

Human resources are valuable for the unique and rare abilities that individuals can bring, particularly at high levels of specialized expertise (Coff \& Kryscynski, 2011). Such resources are related to the number and personal characteristics available to formulate and implement the strategy (Barney, 1991). The most important characteristics of human resources recognized in the literature are individual experience, knowledge and skills (Morgan et al., 2006).

Corporate culture or organizational culture is an important source of competitive advantage, and is defined as a complex set of values, beliefs and assumptions that provide behavioural norms that shape strategy's formulation and execution (Barney, 1986). Casson (1990) argues that corporate culture has influence and impact on firm's structure and performance. Moreover, the firm's ongoing concerns with services and customers satisfaction reflect the set of values that are present in organizational culture (Barney, 1986). Indeed, customer proximity allows firms to gather timely market information and joint development activities and increase brand loyalty (Porter, 1980).

Relational resources are firms' relationships with external entities, such as customers, suppliers, competitors, governmental agencies (Davis \& Mentzer, 2008) and are considered a promising source of sustainable competitive advantage, since they are asymmetrically distributed across firms, imperfectly mobile, difficult to imitate, and have no readily available substitutes (Barney, 1991). Thus, the source of competitive advantage is not only in the internal resources held by firms, but also in the relations which they hold outside (e.g. Dyer \& Singh, 1998; Lavie, 2006).
Currently, in the global age of information and knowledge, competitive advantage based on processes and product is no longer sustainable, the focus has changed to knowledge and learning abilities (Drucker, 1994). Information is a resource that concerns the acquisition and dissemination of knowledge regarding different stakeholders, distribution channels and domestic or foreign markets (Katsikeas \& Morgan, 1994). This important resource and source of competitive advantage changed firms' competitive nature by altering their industries structures and competitive rules and allowing them to perceive new ways to operate and generate a huge number of new businesses (Porter \& Millar, 1985).

However, it is important to distinguish between dynamic capabilities and RBV's capabilities since they are considered to be distinct constructs (Ambrosini \& Bowman, 2009). On one hand, an operational capability is a high level routine (or collection of routines) which, together with the inputs, provides the management a set of decision options for the production of outputs (Winter, 2000). We highlight the term routine, which is understood as a learned behaviour, extremely structured, repetitive and based on technical knowledge. Thus, these operational capabilities allows the company to sustain itself in the present (Winter, 2003), usually involving the execution and the coordination of a variety of tasks to perform an activity, such as production of a particular product (Helfat \& Peteraf, 2003).

\subsection{Absorptive Capacity}

In order to survive certain pressures, companies need to recognize, assimilate and apply new external knowledge for commercial purposes (Jansen, Van Den Bosch \& Volberda, 2005). This ability, known as absorptive capacity (Cohen \& Levinthal, 1990), emerges as an underlying theme in the organizational strategy research (Jansen et al., 2005). Cohen and Levinthal (1990) conceptualize AC as the firms' ability to identify, assimilate, and exploit knowledge acquired from external sources. As such, AC facilitates knowledge accumulation and its subsequent use. Thus, this ability access and use new external knowledge, regarded as an intangible asset, is critical to success and depends mainly on prior knowledge level, since it is this knowledge that will facilitate the identification and processing of new one. This prior knowledge not only includes the basic capabilities, such as shared language, but also recent technological and scientific data or learning skills. By analysing this definition is found that absorptive capacity of knowledge only three dimensions: the ability to acquire external knowledge; the ability to assimilate it inside; and the ability to apply it (Cohen \& Levinthal, 1990). Zahra and George (2002) broaden the concept of AC from the original three dimensions (identify, assimilate, and exploit) to four dimensions (acquire, assimilate, transform, and exploit).

AC is a good example of a dynamic capability since it is embedded in a firm's routines. It combines the firm's resources and capabilities in such a way that together they influence "the 
firm's ability to create and deploy the knowledge necessary to build other organizational capabilities" (Zahra \& George, 2002, p. 188). Firms, therefore, need to continually analyse and interpret changing market trends and quickly recognize new opportunities in order to create competitive products (Tzokas, Kim, Akbar \& Al-Dajani, 2015).

The AC construct encompasses an outward-looking perspective that deals with the identification and generation of useful external knowledge and information and an inward-looking component that is related with how this knowledge is analysed, combined with existing knowledge, and implemented in new products, new technological approaches, or new organizational capabilities (Cohen \& Levinthal, 1990).

Studying absorptive capacity offers fascinating insights for the strategic management literature and provide new information regarding how firms may develop important sources of sustainable competitive advantages (Jansen et al., 2005) and enhance international sales performance (Javalgi, Hall \& Cavusgil, 2014).

Indeed, empirical studies suggest that absorptive capacity enable firms to successfully learn in foreign markets and consequently achieve higher profits or revenue growth from international operations. In other words, firms that compete in international markets have to quickly absorb a huge amount of information to exploit new business opportunities in these markets and gain a competitive advantage (Zahra \& Hayton, 2008). Furthermore, in the international business literature, knowledge about a potential host country has been proposed to influence the speed of firms' international expansion (Fletcher \& Harris, 2012).

\subsection{Export Performance}

The development of exports is of great importance, both at macro and micro levels, contributing to economic and social development of nations, helping the industry to improve and increase productivity and create jobs. At company level, through market diversification, exports provide an opportunity for them to become less dependent on the domestic market, gaining new customers, exploiting economies of scale and achieving lower production costs while producing more efficiently (Okpara, 2009).

In this sense, exports is a more attractive way to enter international markets, especially for SMEs, in comparison with other alternatives, either joint ventures or setting up subsidiaries, which involve spending a large number of resources (e.g. Dhanaraj \& Beamish, 2003; Piercy, Kaleka \& Katsikeas, 1998), does not create high risk and commitment and allows greater flexibility in adjusting the volume of goods to different export markets (Lu \& Beamish, 2002).

On one hand, a company's export activity starts to fulfil certain goals, which may be economic (such as increasing profits and sales) and / or strategic (such as diversification of markets, gaining market share and increasing brand reputation) (Cavusgil
\& Zou, 1994). On the other hand, the export motivation may result from proactive or reactive actions. The proactive actions are advantage of profit, introduction of a single product, technological advantage, and exclusive information, commitment of management, tax benefits and economies of scale. The reactive motivations are identifying competitive pressures, excess production capacity, sales decrease in domestic market, saturation of domestic market and proximity of customers and landing ports (Wood \& Robertson, 1997).

\subsection{Research model and hypotheses derivation}

We present in figure 1 the theoretical model that will be explored in this research, which represents the explanatory variables (export performance) and explained variables (intangible resources and absorptive capacity).

Figure 1 - Research conceptual model

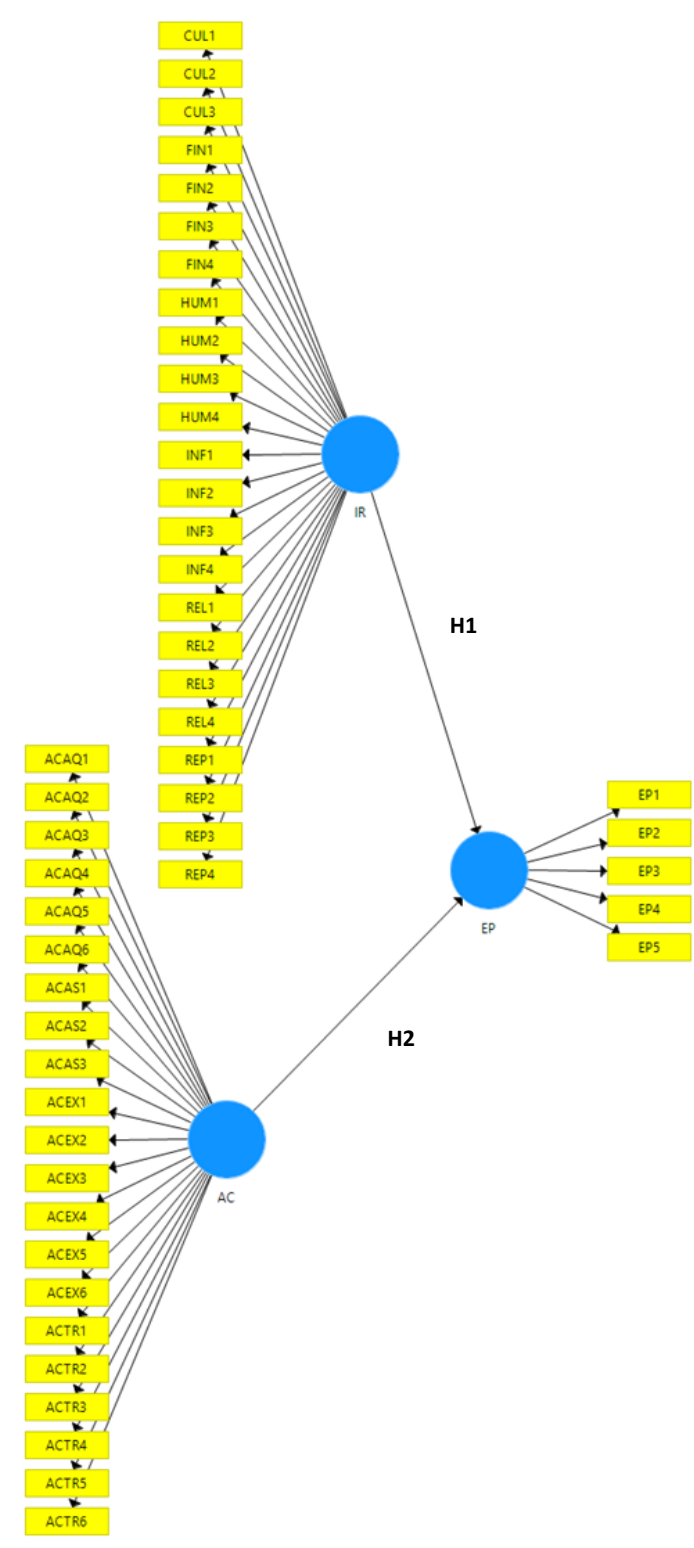

Key: IR - Intangible resources; AC - Absorptive capacity; EP - Export performance.

Source: Own elaboration. 
The RBV argues that firm' performance variations results from the possession of heterogeneous resources. This resources and capabilities heterogeneity leads to performance's imbalances and affects the firm's ability to design and implement competitive strategies (Barney, 1991; Peteraf, 1993). Thus, this theory states that the possession of heterogeneous resources and capabilities directly affects companies' performance (Makadok, 2001; Teece et al., 1997). Newbert (2007) holds that intangible resources, due to its inimitability, are critical to achieving competitive advantage and that the possession of these represents also an important factor in the ability of SMEs to implement strategies that leads to performance's positive results.

Thus, according to this theory, performance differences across firms can be attributed to the heterogeneity in the firms' resources and capabilities (Hitt et al., 2001; Makadok, 2001; Teece et al., 1997). Resources that are valuable, unique, and difficult to imitate can provide competitive advantages (Amit \& Schoemaker, 1993; Barney, 1991). In turn, these advantages provide positive returns (Peteraf, 1993), constituting intangible resources as important variables for company's success (Amit \& Schoemaker, 1993; Barney, 1991).

The most important reputational asset relevant to export performance identified in the literature is brand equity. This concept is associated to a set of assets linked to the name and symbol of the brand that adds value to the initial value of the product or service, such brand name awareness, distinctiveness of brand image, appeal of brand 'personality' and strength of brand image (Morgan et al., 2006). This valuable intangible resource allows the company to build and protect its market share, enhance marketing investments and introduce new products in the export target market more easily (Aaker, 2010).

The most important characteristics of export venture financial resources are the level of financing that can be accessed, and the timeframe within which this can be deployed (Morgan et al., 2006). Accordingly, better access to financial resources increases the likelihood of starting exports and reduce the timeframe of internationalization decisions (Bellone, Musso, Nesta \& Schiavo, 2010).

Human resources allow firms to create an opportunity to achieve competitive advantage. Firms that continuously invest in human resources increase the value creation capabilities on the long run (Hitt \& Duane, 2002). Thus, human capital contributes significantly to firm performance (Hitt et al., 2001). In the context of export ventures, the international business literature indicates that industrial export venture managers think about human resources needed to design and execute the venture's export strategy, in order to contribute to higher performance (Morgan et al., 2006).

Organizational culture allows firms to develop employee morale and motivation, increase work quality and improve productivity and financial performance (e.g. Barney, 1986; Casson, 1990). Cultural resources can be a significant asset for export ventures and is particularly determinant for export performance (Morgan et al., 2006).

The value of relational resources is realized when they are leveraged to make other resources more productive, thereby creating options for managers that provide a competitive edge for the firm. Over time, relational ties among partners become a growing repository of valuable resources and information (Davis \& Mentzer, 2008).

Literature acknowledge that information and knowledge are key resources to build competitive advantage (Morgan, Kaleka \& Katsikeas, 2004) and for superior performance in foreign markets (Morgan et al., 2006).

Thus, this study seeks to test the following hypotheses:

H1: Intangible resources influences positively export performance.

Dynamic capabilities refer to "the firm's ability to integrate, build, and reconfigure internal and external competences to address rapidly changing environments" (Teece et al., 1997, p. 516). By "environment" the RBV literature usually refers to the competitive business environment. Markets had become hypercompetitive, making it increasingly difficult to maintain competitive advantage over time (Barreto, 2010).

Barreto (2010, p. 271) argued that a "dynamic capability is the firm's potential to systematically solve problems, formed by its propensity to sense opportunities and threats, to make timely and market-oriented decisions, and to change its resource base". On the other hand, dynamic capabilities enable companies to create, develop and protect resources allowing them to attain superior performance in the long run, are constructed (not acquired in the market), dependent on experience and are embedded in the company's organizational processes (Ambrosini \& Bowman, 2009), not directly affecting the outputs, but contributing through the impact they have on operational capabilities (Teece et al., 1997).

These capabilities refer to a firm's capacity to deploy resources, usually in combination, using both explicit and tacit elements (such as know-how and leadership). For this reason, capabilities are often firm-specific and are developed over time through complex interactions between the firm's resources (Amit \& Schoemaker, 1993). Maintaining these capabilities requires a management that is able to recognize adversity and trends configure and reconfigure resources, adapt processes and organizational structures in order to create and seize opportunities, while remaining aligned with customer preferences. Indeed, dynamic capabilities allow businesses to achieve superior long-term performance (Teece, 2007). Ultimately, the following hypotheses is tested:

H2: Absorptive capacity influences positively export performance. 


\section{Methods}

\subsection{Setting and data collection}

To test the hypothesis a sample of Portuguese footwear companies was used, that meet the following criteria: companies in which at least $50 \%$ of income comes from exports of goods, or companies in which at least $10 \%$ of income comes from exports of goods and the export value is higher than 150.000 Euros. According to INE (2014), in 2011 there were 380 firms with export profile.

Data collection was implemented through electronic questionnaire, associating a link to the survey that was online. To reduce misunderstandings, the questionnaire was validated by the research department of Portuguese Footwear, Components and Leather Goods Association (APICCAPS).

We were provided with a database of 231 companies (company name, telephone contact, email, economic activity classification, export markets, export intensity and capital origin). Only 167 companies fulfilled the parameters, and were contacted by email by APICCAPS to respond to the questionnaire. Subsequently, all companies were contacted by the authors via e-mail and telephone, to ensure a higher rate of valid responses. The questionnaires began on April 22, 2014 and ended on July 22, 2014. After finishing the data collection period, 42 valid questionnaires were received, representing a $25 \%$ response rate. This response rate is considered quite satisfactory, given that the average of top management survey response rates are in the range of $15 \%-20 \%$ (Menon, Bharadwaj, Adidam \& Edison, 1999).

By comparing means, using for this purpose the one-sample $t$ test, we found that the mean difference, which reflects the difference between the sample mean and the test value, is within the $95 \%$ confidence interval and $p<0.001$ level of significance. Therefore, the sample is representative of the population.

\subsection{Measures}

For assessment of intangible resources was used Morgan et al.'s scale (2006), comprising four questions for reputational resources, four questions for access to financial resources, four questions for human resources, three questions for cultural resources, four questions for relational resources and four questions for informational resources. A five point Likert scale was used to measure each item, where 1 means "strongly disagree" and 5 "strongly agree".

To measure absorptive capacity construct, and based in Jansen et al. (2005), it was operationalized the company's ability to acquire new knowledge through six questions, assimilate it through three questions, transform it through three questions and the ability to explore new external knowledge into their current operations, through six questions (e.g. Jansen et al., 2005; Zahra \& George, 2002). A five point Likert scale was used to measure each item, where 1 means "strongly disagree" and 5 "strongly agree".
Okpara's scale (2009) was used to assess export performance, comprising profitability indicators of sales growth, profit, activities, operations and performance in general. A five point Likert scale was used to measure each item, where 1 means "strongly disagree" and 5 "strongly agree". It is important to note that companies evaluated absorptive capacity and export performance relative to their major competitors in the export market(s).

Lumpkin and Dess (1996) refer the existence of firms' specific factors that can affect growth and performance. In this context, we use age and size as control variables. Age the number of years a firm is operating in an industry (George, 2005), while size is defined by European Union (EU) criteria (EU recommendation 2003/361 micro, small, medium-sized firms).

Wiklund and Shepherd (2005) defend that businesses of different size and age may exhibit different organizational characteristics, which in turn may influence performance. Several studies recognised that such characteristics are correlated with export performance (Beamish et al., 1999; Cavusgil, 1984; Leonidou, 1998; Sousa, Martínez-López \& Coelho, 2008).

Age is related to international experience; however, there is no consensus on the impact of this variable in performance. While some authors (e.g. Dean, Menguç \& Myers, 2000; Lado, Martinez-Ros \& Valenzuela, 2004) confirmed the existence of a significant and positive relationship between experience and performance; others (e.g. Baldauf, Cravens \& Wagner, 2000; Brouthers \& Nakos, 2005) defend that international experience is negatively related to export performance.

There is some controversy in the literature regarding the impact of size on business performance (e.g. Brouthers \& Nakos, 2005; Kaynak \& Kuan, 1993). If, on one hand, the international business literature suggests that larger companies possess more financial and human resources, as well other resources and capabilities, which enhance export activity and success (Bonaccorsi, 1992; Katsikeas, Deng \& Wortzel, 1997), on the other hand, some studies found no significant relationship between the firm's size and export performance (Contractor, Hsu \& Kundu, 2005; Moen, 1999; Wolff \& Pett, 2000).

\section{Results}

\subsection{Descriptive analysis}

Table 1 presents descriptive statistics and the correlations between the constructs and the control variables. We use a non-parametric test, Spearman correlation, due to the nature of variables (ordinals), data and sample size (Marôco, 2011; Pestana \& Gageiro, 2008). The table presents no anomalous results in the constructs' means and standard deviation and constructs correlations are moderate and significant. The same cannot be said, however, of the relationship between constructs and control variables. Even though correlations being an indicator of constructs convergent validity, we proceed with the process of properly validate the scale. 
Table 1 - Mean, standard deviation and correlation coefficients

\begin{tabular}{|c|c|c|c|c|c|}
\hline Construct & (1) & (2) & (3) & (4) & (5) \\
\hline (1) Intangible resources & 1.000 & & & & \\
\hline (2) Absorptive capacity & $.587^{*}$ & 1.000 & & & \\
\hline (3) Export performance & $.493^{*}$ & $.656^{*}$ & 1.000 & & \\
\hline (4) Age & $.012^{*}$ & $-.009 *$ & -.016 & 1.000 & \\
\hline (5) Size & $.093^{*}$ & $-.044^{*}$ & $.227^{*}$ & $.035^{*}$ & 1.000 \\
\hline Mean & 3.46 & 3.61 & 3.87 & 2.69 & 2.90 \\
\hline Standard deviation & .695 & .797 & .803 & 1.440 & 370 \\
\hline $\mathrm{n}$ & 42 & 42 & 42 & 42 & 42 \\
\hline
\end{tabular}

Source: Own elaboration.

\subsection{Reliability analysis}

In order to verify the reliability of overall variables we estimated the stability and internal consistency through Cronbach's alpha $(\alpha)$. Generally, an instrument or test is classified with appropriate reliability when $\alpha$ is higher or equal to 0.70 (Nunnally, 1978). However, in some research scenarios in social sciences an $\alpha$ of 0.60 is considered acceptable, as long as the results are interpreted with caution and the context is taken into account (DeVellis, 2012). For the present study we used the scale proposed by Pestana and Gageiro (2008).

The result of 0.939 achieved for all of variables is considered excellent, confirming the sample's internal consistency. It was also conducted an internal consistency test for all variables in each construct to assess their reliability (Table 2 ).

Table 2 - Internal consistency test by construct (Cronbach's Alpha)

\begin{tabular}{|l|c|c|c|c|}
\hline \multicolumn{1}{|c|}{ Construct } & Cronbach's $\boldsymbol{\alpha}$ & Items Nr. & $\mathbf{n}$ & Analysis \\
\hline Intangible resources & .924 & 23 & 42 & Excellent \\
\hline Absorptive capacity & .924 & 21 & 42 & Excellent \\
\hline Export performance & .927 & 5 & 42 & Excellent \\
\hline
\end{tabular}

We found that absorptive capacity and export performance have excellent consistency.

\subsection{Exploratory factor analysis}

\subsubsection{Intangible resources}

We performed a factor analysis, with Varimax rotation, of the intangible resources construct items that comprise the scale, with the purpose of finding a solution that was more easily interpretable. Five factors were extracted and there was no need to delete items. Thus, we obtained a scale composed of 23 items, distributed over five factors that explain $83.32 \%$ of total variance, with $56.37 \%$ of variance explained by the first factor (called Human and Cultural Resources, which gather seven items whose saturations range between 0.861 and 0.498 ), 9.05\% for the second factor (named Access to Financial Resources and is divided into four items and their saturations range between 0.864 and 0.836 .), $7.61 \%$ by the third factor (called Informational Resources, composed of four items, whose saturations range between 0.849 and 0.708 ), $5.42 \%$ for the fourth factor (named Reputational Resources and is divided into four items and their saturations range between 0.819 and 0.695 .) and, finally, $4.86 \%$ by the fifth factor (called Relational Resources, composed of four items, whose saturations range between 0.800 e 0.607).

Analysing the internal consistency of the five factors, we found that Cronbach's Alphas are $\alpha=0.943, \alpha=0.962, \alpha=0.882, \alpha=0.905$ and $\alpha=0.949$, respectively, values that signify that the construct's dimensions have a good ( $3^{\text {rd }}$ factor) and a very good (all the other factors) internal consistency. KMO test indicates that there is a very good correlation between the variables (0.832). Bartlett's sphericity test registered a value of $\chi^{2}(253, n=42)=1608.609$, $p<0.05$, therefore is confirmed that $\chi^{2}>\chi_{0.95}{ }^{2}$, so the null hypothesis is rejected, i.e. the variables are correlated.

\subsubsection{Absorptive capacity}

In the factor analysis, with Varimax rotation, of these construct we got a scale with 21 items, distributed by 5 factors, that explained $73.89 \%$ of total variance: $44.35 \%$ by the first factor (Knowledge Exploitation, with 7 items, whose saturations range between 0.838 and 0.328 ), $10.92 \%$ by second factor (Knowledge Assimilation, with 4 items, whose saturations range between 0.807 and 0.670 ), $8.28 \%$ by third factor (General Knowledge Acquisition, with 3 items, whose saturations range between 0.768 and 0.670 ), $5.46 \%$ by fourth factor (Knowledge Acquisition in the Industry, with 3 items, whose saturations range between 0.816 and 0.404 ) and $4,88 \%$ by the fifth factor (Knowledge Transformation, with 2 items, whose saturations range between 0.696 and 0.580 ).

The internal consistency of the five factors are, respectively, $\alpha=0.931, \alpha=0.860, \alpha=0.710, \alpha=0.650$ and $\alpha=0.796$. These values indicate that these dimensions presented a reasonable $\left(3^{\text {rd }}, 4^{\text {th }}\right.$ and $5^{\text {th }}$ factors $)$, a good ( $2^{\text {nd }}$ factor $)$ and a very good $\left(1^{\text {st }}\right.$ factor) internal consistency. KMO test confirm a medium correlation between the variables (0.796). Bartlett's sphericity 
test registered a value of $\chi^{2}(210, \mathrm{n}=42)=630.742, p<0.05$, therefore is confirmed that $\chi^{2}>\chi_{0.95}{ }^{2}$, so the null hypothesis is rejected and the variables are correlated.

\subsubsection{Export performance}

Lastly, in the factor analysis, with Varimax rotation, of these construct we got a scale with one factor and there was no need to delete items. A scale with 5 items was obtained, which explained $77.9 \%$ of total variance, whose saturations range between 0.918 and 0.850 .

The internal consistency is excellent ( $\alpha=0.927)$. KMO test point to a good correlation between the variables (0.814). Bartlett's sphericity test registered a value of $\chi^{2}(10, n=42)=171.982$, $p<0.05$, therefore is confirmed that $\chi^{2}>\chi_{0.95}{ }^{2}$, so the null hypothesis is rejected and the variables are correlated.

\subsection{Structural equation model}

The structural equation model is a multiple regression analysis, with reflective indicators that are presented as an image of the unobserved theoretical construct, representing observed variables or measures, with the objective of strengthening the relationship of influence between the constructs (Marôco, 2011). The simple correlation between these indicators with their construct must have a value equal to or higher than 0.707 so that the shared variance between the construct and their indicators is higher than the error variance (Carmines \& Zeller, 1979).

Partial Least Squares (PLS) is a technique that best fits predictive applications (exploratory analysis) and theory development when it is not soundly established (Cepeda \&Roldán, 2014). This technique, on one hand, maximize the explained variance of the dependent variables (latent or observed, or both) and estimate structural models with small samples (Chin \& Newsted, 1999; Reinartz, Haenlein \& Henseler, 2009). On the other hand, it estimates reflective and formative measurement models without identification problems (Chin, 2010). PLS appear to be a preferable option for researchers with samples below 250 observations (42 in this study) (Reinartz et al., 2009).
In order to verify the reliability of overall variables we estimated the stability and internal consistency through Cronbach's alpha $(\alpha)$. Generally, an instrument or test is classified with appropriate reliability when $\alpha$ is higher or equal to 0.70 (Nunally, 1978; Chin, 2010). The result of 0.939 achieved for all variables is considered excellent, confirming the sample's internal consistency (Pestana \& Gageiro, 2000). Table 3 shows all constructs largely achieved the required level.

Table 3 - Cronbach's Alpha

\begin{tabular}{|c|c|c|}
\hline Construct & Cronbach Alpha & $p$ values \\
\hline IR & .964 & .000 \\
\hline$A C$ & .931 & .000 \\
\hline EP & .929 & .000 \\
\hline
\end{tabular}

Source: Own elaboration.

We also use the composite reliability coefficient to assess construct validity (Chin, 1998). This coefficient reflects construct adequacy for a level higher than 0.6 using confirmatory factor analysis (Gefen \& Straub, 2005), as in our case. Table 4 illustrates that the studied constructs (all multidimensional) highly exceeded the minimum required for a good fit.

Table 4 - Composite reliability

\begin{tabular}{|l|c|c|c|}
\hline Construct & Composite reliability & p values & R2 \\
\hline IR & .967 & .000 & \\
\hline AC & .940 & .000 & \\
\hline EP & .946 & .000 & .448 \\
\hline
\end{tabular}

A mere comparison of the regression coefficients is not valid to evaluate the importance of each independent variable models, since these variables have different magnitudes. Thus, it is essential to use standard variables, known as Beta ( $\beta$ ) coefficients, in the models adjustment so that the independent variables can be compared. By analysing the standardized Beta coefficients (Table 5) it is confirmed which variables have higher contribution to exports performance.

Table 5 - Estimates of $\beta$ coefficients in the regression models

\begin{tabular}{|l|c|}
\multicolumn{1}{|c|}{ Regression 1 - INTANGIBLE RESOURCES } & $\boldsymbol{\beta}$ \\
\hline Human and Cultural Resources & $.178^{* * *}$ \\
\hline Access to Financial Resources & $.277^{* *}$ \\
\hline Informational Resources & $.072^{* * *}$ \\
\hline Reputational Resources & $.325^{*}$ \\
\hline Relational Resources & $.182^{* *}$ \\
\hline \multicolumn{1}{|c|}{ Regression 2 - ABSORPTIVE CAPACITY } \\
\hline Knowledge Exploitation & $.442^{*}$ \\
\hline Knowledge Assimilation & $.241^{*}$ \\
\hline General Knowledge Acquisition & $.280^{*}$ \\
\hline Knowledge Acquisition in the Industry & $.103^{*}$ \\
\hline Knowledge Transformation & $.313^{*}$ \\
\hline
\end{tabular}

Dependent variable: Export performance. $/ * p<0,05 . / * * p<0,1$. / ***n.s. non-significant.

Source: Own elaboration. 
On one hand, from the intangible resources perspective Reputational Resources $(\beta=0.325)$, Access to Financial Resources $(\beta=0.277)$ and Relational Resources $(\beta=0.182)$, on the other hand, from the absorptive capacity perspective, a Knowledge Exploitation $(\beta=0.442)$, a Knowledge Transformation $(\beta=0.313)$ and a General Knowledge Acquisition $(\beta=0.280)$ are the ones that have higher relative contributions to explain exports performance.

For validity assessment, two subtypes are usually examined: convergent and discriminant validity. Convergent validity implies that a set of indicators represents one and the same underlying construct (Henseler et al., 2009). Fornell and Larcker (1981) suggest using the Average Variance Extracted (AVE) criterion and that an AVE value of at least 0.5 indicates sufficient convergent validity. Table 6 demonstrates that only absorptive capacity is below the minimum required.

Table 6 - Convergent validity

\begin{tabular}{|c|c|c|}
\hline Construct & AVE & $p$ values \\
\hline IR & .561 & .000 \\
\hline$A C$ & .442 & .000 \\
\hline EP & .778 & .000 \\
\hline
\end{tabular}

Source: Own elaboration.

Discriminant validity is the degree to which any single construct is different from the other constructs in the model. To have discriminant validity a construct must exhibit weak correlations with other latent variables that measure different phenomena. There are two measures of discriminant validity in PLS. The Fornell-Larcker criterion (1981) recommends that the AVE should be greater than the variance between a given construct and the other with which it shares the model. The second criterion suggests that the loading of each indicator is expected to be greater than all of its cross-loadings (Henseler et al., 2009).

We can observe the explanatory power of each variable in the model. Entrepreneurial orientation is the only purely explanatory variable and reputational resources and absorptive capacity of knowledge exploitation the explained variables. Chin (1998) distinguishes the explanatory power from moderate to substantial. Table 7 expresses the good results in terms of discriminant validity of the research model, confirming that constructs do differ significantly.

Table 7 - Discriminant validity

\begin{tabular}{|l|l|l|l|}
\hline \multicolumn{1}{|c|}{$\begin{array}{c}\text { Fornell-Larcker } \\
\text { Criterion }\end{array}$} & IR & AC & EP \\
\hline IR & .749 & & \\
\hline AC & .587 & .665 & \\
\hline EP & .492 & .656 & .882 \\
\hline
\end{tabular}

In order to determine the significance of the studied relationships and the confidence intervals of the path coefficients, we used bootstrapping technique $(5,000$ subsamples). The weighted coefficients indicate the relative strength of each exogenous construct. According to Chin (1998), relationships between constructs, with structural coefficients higher than 0.2 , are considered robust. From table 8 , we thus conclude that the original model does not present non-significant paths.

Table 8 - Path Coefficients

\begin{tabular}{|l|c|c|c|c|c|}
\hline \multicolumn{1}{|c|}{ Hypotheses } & $\begin{array}{c}\text { Original Sample } \\
\text { (O) }\end{array}$ & $\begin{array}{c}\text { Sample } \\
\text { Mean (M) }\end{array}$ & $\begin{array}{c}\text { Standard } \\
\text { Error (STERR) }\end{array}$ & $\begin{array}{c}\text { T Statistics } \\
\text { (|O/STERR|) }\end{array}$ & $p$ values \\
\hline IR -->+EP & .162 & .156 & .120 & 1.354 & $.076^{*}$ \\
\hline AC -->+EP & .561 & .597 & .102 & 5.523 & $.000^{* *}$ \\
\hline${ }_{p}^{*} p<0.1 ; * * 0.001$. & & & & & \\
\hline
\end{tabular}

Source: Own elaboration.

This model explains 44.8 per cent of the variance in export performance. This result is satisfactory, since most previous research using linear models typically explain less than 40 per cent (Liñán \& Chen, 2009). The significance of structural coefficients and the magnitude of the total effects enabled us to test the research hypotheses, having registered the following results:
H1. IR --> +EP - This hypothesis was supported;

H2. AC -->+EP - This hypothesis was supported;

Figure 2 presents the final research structural model with the (direct) effects and explained variance of latent variables. 


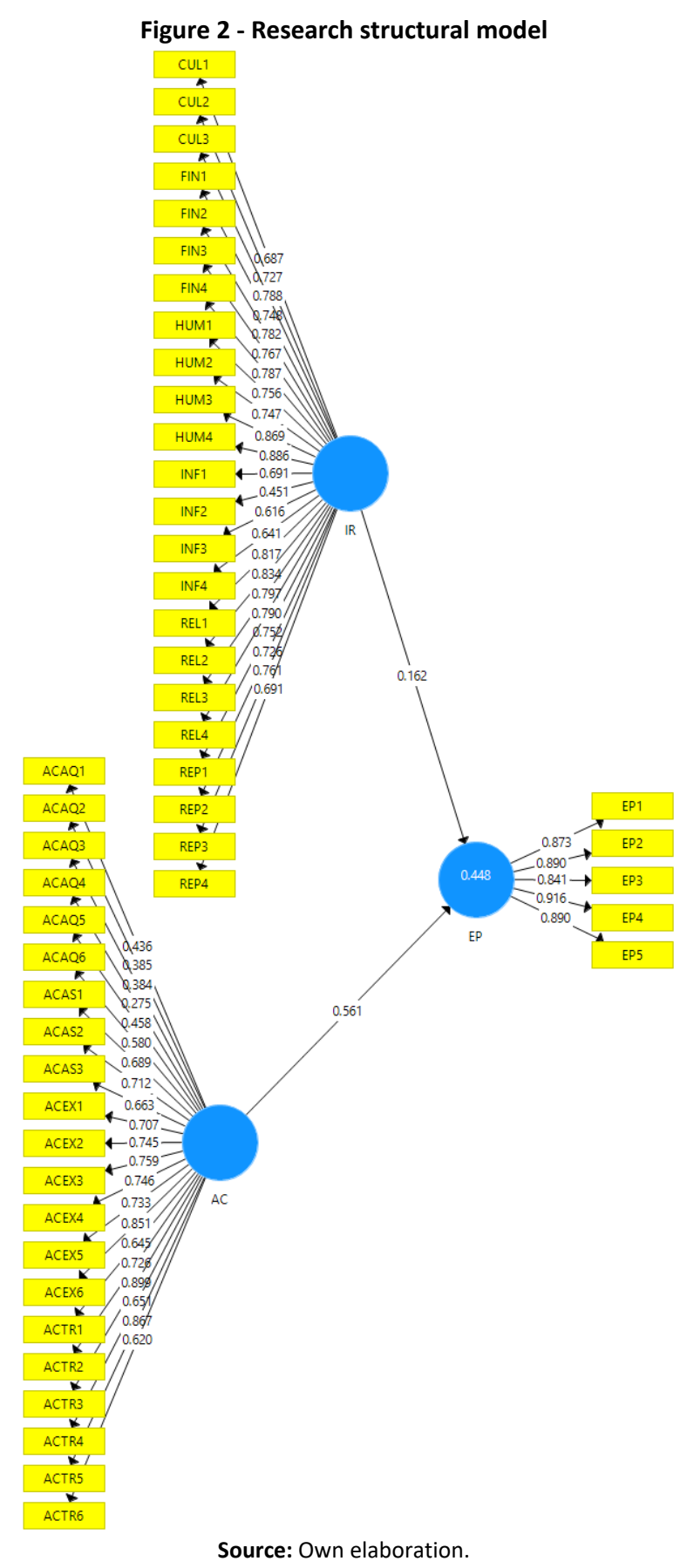

\section{Discussion and conclusions}

The main purpose of this study is to analyse the influence of intangible resources and absorptive capacity on export performance of SMEs. We conducted an empirical research based on a sample of 42 companies, which were applied a questionnaire in order to exploit data to test hypotheses, using proceedings and statistical techniques. It is important to note that companies evaluated absorptive capacity and export performance relative to their major competitors in the export market(s), so the results should be interpreted based on these two aspects.

The Portuguese footwear industry faces considerable challenges, not only concerning the international markets crisis, but also regarding consumption patterns. The reduction of shoe design lifecycles has consequences on the offer. On one hand, the products have to be adapted to different segments specific needs and tastes (custom design, new models in small series, etc.), on the other hand, manufacture processes must be increasingly flexible, adopt just-in-time production, invest in the brand, qualified personnel, technology and innovation (APICCAPS, 2013).

Findings provided evidence that intangible resources and absorptive capacities have a positive and significant influence on export performance ( $\mathrm{H} 1$ and $\mathrm{H} 2$ supported) in the context of Portuguese footwear industry's. These results corroborate those of other existing empirical studies, as follows is based.

The dimensions of the intangible resources that have a relative greater influence on the performance of exports are, respectively, reputational resources $(\beta=0.325)$, access to financial resources $(\beta=0.277)$ and relational resources $(\beta=0.182)$.

The most important reputational asset relevant to export performance identified in the literature is brand equity. This concept is associated to a set of assets linked to the name and symbol of the brand that adds value to the initial value of the product or service, such brand name awareness, distinctiveness of brand image, appeal of brand 'personality' and strength of brand image (Morgan et al., 2006). This valuable intangible resource allows the company to build and protect its market share, enhance marketing investments and introduce new products in the export target market more easily (Aaker, 2010). Aaker (1991) identifies brand awareness as the potential customer ability to recognize that a brand has certain category. This recognition helps a brand to distinguish from others. Brand associations consist of brand-related thoughts, feelings, perceptions, smells, colours, music, images, experiences, beliefs and attitudes (Kotler \& Keller, 2011). Brand loyalty is defined as the attachment that a customer has to a brand. Perceived quality can be defined as customers' judgment about a product's overall excellence or superiority. Consequently, perceived quality is an overall feeling about a brand and does not imply the actual quality of a product (Aaker, 1991).

In international markets the most important characteristics of financial resources are the level of financing that can be accessed and the timeframe within which this can be deployed (Morgan et al., 2006). In this sense, a better access to financial resources increases the likelihood of initiating exports and reduce internationalization's time-to-decision (Bellone et al., 2010). Firms with financial resources tend to respond more quickly to market changes and to achieve more easily competitive advantage (Chesbrough \& Teece, 2002). The access to capital enables organizations to learn and overcome challenges as well investing in intensive capital projects in order to protect existing markets or enter in new markets (Westhead et al., 2001). Thus, financial capital is an important resource, however its relevance is in the access and not on the property (Wiklund \& Shepherd, 2005). 
Relational resources concern the number, strength and quality of existing relationships with the several stakeholders, which, according to Barney (1991), are a promising sources of sustainable competitive advantage because they are asymmetrically distributed across firms, imperfectly mobile, difficult to imitate, and have no readily available substitutes. Thus, the sources of competitive advantage are not only on internal resources that are owned or controlled by the firm (e.g. Amit \& Schoemaker, 1993; Barney, 1991; Peteraf, 1993; Teece et al., 1997; Teece, 2007), but are also in the external relationships (e.g. Dyer \& Singh, 1998; Lavie, 2006). The relational resources create value when they are used to make other resources more productive, thereby creating a competitive edge for the firm. So, by accumulating relationships, firms will hold a repository of valuable external resources and information (Davis \& Mentzer, 2008). Indeed, in the international markets, relational resources provide a firm with access to information, resources, markets and technologies; with advantages from learning, scale and scope economies, sharing risks and outsourcing value-chain activities (Gulati, Nohria, \& Zaheer, 2000). Moreover, contacts can be leveraged to obtain knowledge, timely information, funding, credibility, and other desirable assets (Chisholm \& Nielsen, 2009).

On the other hand, the absorptive capacity's dimensions that have higher relative contributions to explain exports performance are, respectively, knowledge exploitation $(\beta=0.442)$, knowledge transformation $(\beta=0.313)$ and general knowledge acquisition $(\beta=0.280)$.

This study also demonstrated that the company's absorptive capacity has a positive and significant influence on their performance. The analysed companies are able to acquire, transform and exploit knowledge through informal knowledge gather, clear definition of tasks, analysis and discussion of market trends and new product development, among others. Interestedly, however, firms do not value knowledge acquisition in the industry.

Dynamic capabilities can take a variety of forms and be involved in different functions, but the most important common characteristics are that they are higher level capabilities which provide opportunities for knowledge gathering and sharing, constant updating the operational processes, interaction with the environment, and decision-making evaluations (EasterbySmith, Lyles, \& Peteraf, 2009). However, the existence of common features does not imply that any particular dynamic capability is exactly alike across firms, rather they could be developed from different starting points and take unique paths (Eisenhardt \& Martin, 2000).

In fact, according to the industrial organization, a company should find a favourable position in its industry from which it can better defend against competitive forces, or to influence them in his favour through strategic actions such as raising barriers to entry, etc. (Porter, 1980). This perspective is consistent with Eisenhardt and Martin (2000) regarding the uniqueness of paths. The results of this study confirm that dynamic capabilities enable firms to achieve superior long-term performance (Teece, 2007).

\subsection{Theoretical and practical implications}

The findings of this study will have important implications for both academics and practitioners. By building on the literature of intangible resources, absorptive capacity and export performance, this study aims to support the strategic development of business management policies designed to increase firms' performance in foreign markets and add value to the current context of change. In addition, the results will provide guidance to business practitioners; because they will indicate which intangible resources and absorptive capacities are the best predictors for export success. The study adds to the constructs' literature by empirically validating it as a latent construct that captures the dimensions of reputational resources, access to financial resources, human resources, cultural resources, relational resources and, informational resources, concerning intangible resources, and of acquiring, assimilating, transforming and exploiting knowledge, concerning absorptive capacities.

It is known that strategy includes deliberate and emergent initiatives adopted by management, comprising resource and capabilities use to improve business performance (Nag, Hambrick \& Chen, 2007). The findings are a contribution to clarify the influence of intangible resources and absorptive capacity on the company's exports performance. This study also enabled a thorough analysis of a highly important industry for national exports, such as footwear industry, allowing understanding that absorptive capacity, as an industry strategic determinant, enhancing exports performance.

To stay competitive, companies must make an internal assessment in order to find what resources and capabilities give them advantage over competitors. Thus, the challenge of strategy consists in selecting or creating an environmental context where capabilities and resources can provide competitive advantages (Porter \& Montgomery, 1998).

Jansen et al. (2005) defend that companies need to develop organizational mechanisms to combine and apply newly acquired knowledge in order to deal and enhance each absorptive capacity dimension. In this study is notorious the importance of knowledge absorptive capacity to business performance. It is essential that business owners are able to interpret, integrate and apply external knowledge in order to systematically analyse change in the target market and to incorporate this knowledge in their processes to enhance performance.

In addition, the results provide guidance to business practitioners; because they indicate which intangible resources and absorptive capacities are the best predictors for export success. Companies are a bundle of resources and capabilities (Peteraf, 1993), it is essential to understand and identify which resources are relevant to gain competitive advantage and superior performance. In this study it is obvious the importance 
of absorptive capacity to the firms' performance. Business owners must be able to interpret, integrate and apply external knowledge in order to systematically analyse the changes that arise in their target market(s) and to incorporate this knowledge into their processes, to identify the present and future needs and market trends, anticipate changes in demand and seek new business opportunities.

By building on the literature of intangible resources, absorptive capacity and export performance, this study aims to support the strategic development of business management policies designed to increase firms' performance in foreign markets and add value to the current context of change.

\subsection{Research limitations}

The main limitation of this study is related to the sample size, since it was difficult to find companies with the willingness to collaborate in this type of research. The sample is nonprobabilistic and convenience and cannot be used to infer to the general population. The study findings should therefore be analysed with caution.

Most responses were based on subjective judgment of respondents. Although the literature identifies the advantages of subjective measures to evaluate the exports performance, it is recognized that some answers may not represent the reality of business performance in foreign markets.

\subsection{Future lines of research}

In future work, we suggest that the model is used in a sample with a higher number of observations to confirm these results.

We further suggest pursuing with the investigation of strategic management in Portugal, focusing in other sectors of national economy, so that in the future one can make a comparison with similar studies, allowing to find an understand new factors that enhance exports performance.

Future research should combine the paper's findings with further financial statements in order to extend this research data basis with information from a different source, since mixing sources would provide the research with more results' credibility, rather than relying only on a questionnaire.

The researcher might also consider a different focus for future research. The present paper's underlying supposition is certain homogeneity in strategy and behaviour among firms, but we acknowledge that inside a manufacturing sector it is possible to find different profiles of strategic behaviour to face export growth, and, therefore, different determinants of export performance.

The moderating effect of strategic variables (e.g. entrepreneurial orientation, competitive advantage, environment hostility) in the relationship between intangible resources, absorptive capacity and export performance should be also studied.

Finally, exports are considered an economic growth engine. Therefore, future empirical research should focus on studying the impacts of FDI, intangible resources and absorptive capacity in export performance in host countries.

\section{References}

Aaker, D. A. (1991). Managing Brand Equity. Capitalizing on the Value of a Brand Name. New York: Free Press.

Aaker, D. A. (2010). Building Strong Brands. New York: Free Press.

Ambrosini, V., \& Bowman, C. (2009). What are dynamic capabilities and are they a useful construct in strategic management? International Journal of Management Reviews, 11(1), 29-49.

Amit, R., \& Schoemaker, P. (1993). Strategic assets and organizational rent. Strategic Management Journal, 14(1), 33-46.

APICCAPS (2013). Footure - Plano Estratégico - Cluster do Calçado, Porto: APICCAPS

Arnold, J. (2015). Boosting export performance in Portugal. OECD Economics Department Working Papers, 1257. doi:10.1787/18151973

Baldauf, A., Cravens, D. W., \& Wagner, U. (2000). Examining determinants of export performance in small open economies. Journal of World Business, 35(1), 61-88.

Barney, J. (1986). Organizational culture: can it be a source of sustained competitive advantage? Academy of Management Review, 11(3), 656-665.

Barney, J. (1991). Firm Resources and Sustained Competitive Advantage. Journal of Management, 17(1), 99-120.

Barney, J. (2001). Resource-based theories of competitive advantage: A ten-year retrospective on the resource-based view. Journal of Management, 27(6), 643-650.

Barney, J., Ketchen, D. J., \& Wright, M. (2011). The Future of ResourceBased Theory: Revitalization or Decline? Journal of Management, 37(5), 1299-1315.

Barreto, I. (2010). Dynamic Capabilities: A Review of Past Research and an Agenda for the Future. Journal of Management, 36(1), 256-280.

Beamish, P.W., Karavis, L., Goerzen, A., \& Lane, C. (1999). The relationship between organizational structure and export performance. Management International Review, 39, 37-54.

Bellone, F., Musso, P., Nesta, L., \& Schiavo, S. (2010). Financial Constraints and Firm Export Behaviour. The World Economy, 33(3), 347-373.

Bonaccorsi, A. (1992). On the relationship between firm size and export intensity. Journal of International Business Studies, 23(4), 605-636.

Bowman, C., \& Ambrosini, V. (2003). How the Resource based and the Dynamic Capability Views of the Firm Inform Corporate level Strategy. British Journal of Management, 14(4), 289-303.

Brouthers, L. E., \& Nakos, G. (2005). The role of systematic international market selection on small firms' export performance. Journal of Small Business Management, 43(4), 363-381.

Camisón, C., \& Forés, B. (2010). Knowledge absorptive capacity: New insights for its conceptualization and measurement. Journal of Business Research, 63(7), 707-715.

Carmines, E. G., \& Zeller, R. A. (1979). Reliability and Validity Assessment. Newbury Park, CA: Sage Publications.

Casson, M. (1990). Entrepreneurial Culture as a Competitive Advantage. Research in Global Business Management, 1, 139-151.

Cavusgil, S. T. (1984). Differences among exporting firms based on their degree of internationalization. Journal of Business Research, 12(2), 195-208. Cavusgil, T., \& Zou, S. (1994). Marketing strategy-performance relationship: an investigation of the empirical link in export market ventures. Journal of Marketing, 58(1), 1-21.

Cepeda, G., \& Roldán, J. L. (2004). Aplicando en la práctica la técnica PLS en la Administración de Empresas. XIV Congreso Nacional ACEDE, 74-78.

Chesbrough, H., \& Teece, D. (2002). Organizing for innovation: when is virtual virtuous? The Innovative Enterprise, (August), 127-134.

Chin, W. W. (1998). The Partial Least Squares Approach to Structural Equation Modelling. Lawrence Erlbaum Associates, Publisher. Mahwah, New Jersey. London. 
Chin, W. W. (2010). How to write up and report PLS analyses. In V. Esposito Vinzi, W. W. Chin, J. Henseler \& H. Wang (eds.), Handbook of partial least squares: Concepts, methods and applications, (pp. 655690). Berlin, Germany: Springer-Verlag.

Chin, W. W. \& Newsted, P. R. (1999). Structural Equation Modeling Analysis with Small Samples Using Partial Least Squares. In R. Hoyle (ed.), Statistical Strategies for Small Sample Research (pp. 307-341). Thousand Oaks, CA: Sage Publications.

Chisholm, A., \& Nielsen, K. (2009). Social Capital and the ResourceBased View of the Firm. International Studies of Management \& Organization, 39(2), 7-32.

Coff, R., \& Kryscynski, D. (2011). Invited Editorial: Drilling for MicroFoundations of Human Capital-Based Competitive Advantages. Journal of Management, 37(5), 1429-1443.

Cohen, J. A. (2005). Intangible Assets: Valuation and Economic Benefit. Wiley. Cohen, W., \& Levinthal, D. (1990). Absorptive Capacity: A New Perspective on Learning and Innovation. Administrative Science Quarterly, 35(1), 128-152.

Contractor, F. J., Hsu, C.-C., \& Kundu, S. K. (2005). Explaining export performance: a comparative study of international new ventures in Indian and Taiwanese software industry. Management International Review, 45(3), 83-110.

Cretu, A. E., \& Brodie, R. J. (2007). The influence of brand image and company reputation where manufacturers market to small firms: A customer value perspective. Industrial Marketing Management, 36(2), 230-240.

Davis, D., \& Mentzer, J. (2008). Relational Resources in Interorganizational Exchange: The Effects of Trade Equity and Brand Equity. Journal of Retailing, 84(4), 435-448.

Dean, D. L., Menguç, B., \& Myers, C. P. (2000). Revisiting firm characteristics, strategy, and export performance relationship: a survey of the literature and an investigation of New Zealand small manufacturing firms. Industrial Marketing Management, 29(5), 461-477.

DeVellis, R. F. (2012). Scale Development - Theory and Applications (3a ed.). USA: SAGE Publications, Inc.

Dhanaraj, C., \& Beamish, P. W. (2003). A Resource-Based Approach to the Study of Export Performance. Journal of Small Business Management, 41(3), 242-261.

Drucker, P. (1994). The theory of business. Harvard Business Review, 95-104.

Dyer, J. H., \& Singh, H. (1998). The relational view: cooperative strategy and sources of interorganizational competitive advantage. Academy of Management Review, 23(4), 660-679.

Easterby-Smith, M., Lyles, M. A., \& Peteraf, M. A. (2009). Dynamic Capabilities: Current Debates and Future Directions. British Journal of Management, 20, S1-S8.

Eisenhardt, K. M., \& Martin, J. A. (2000). Dynamic capabilities: what are they? Strategic Management Journal, 21(10-11), 1105-1121.

Fletcher, M., \& Harris, S. (2012). Knowledge acquisition for the internationalization of the smaller firm: Content and sources. International Business Review, 21(4), 631-647.

Fornell, C., \& Larcker, D. F. (1981). Evaluating structural equation models with unobservable variables and measurement error. Journal of Marketing Research, 18(1), 39-50.

Gatzert, N. (2015). The impact of corporate reputation and reputation damaging events on financial performance: Empirical evidence from the literature. European Management Journal, 33(6), 485-499.

Gebauer, H., Worch, H., \& Truffer, B. (2012). Absorptive capacity, learning processes and combinative capabilities as determinants of strategic innovation. European Management Journal, 30(1), 57-73.

Gefen, D., \& Straub, D. (2005). A practical guide to factorial validity using PLS-graph: tutorial and annotated example. Communications of the Association for Information Systems, 16, 91-109.

George, G. (2005). Slack resources and the performance of privately held firms. Academy of Management Journal, 48(4), 661-676.
Gulati, R., Nohria, N., \& Zaheer, A. (2000). Strategic networks. Strategic Management Journal, 21(3), 203-215.

Hair, J. F., Black, W. C., Babin, B. J., \& Anderson, R. E. (2014). Multivariate Data Analysis (7th ed.). Pearson Education Limited.

Hall, R. (1992). The strategic analysis of intangible resources. Strategic Management Journal, 13(2), 135-144.

Helfat, C. E., \& Peteraf, M. a. (2003). The dynamic resource-based view: capability lifecycles. Strategic Management Journal, 24(10), 997-1010.

Henseler, J., Ringle, C. M., \& Sinkovics, R. R. (2009). The use of Partial Lesat Squares Path Modeling in international marketing. In R. R. Sinkovics \& P. N. Ghauri (ed.), New Challenges to International Marketing (Advances in International Marketing), 20 (pp. 277-319). Emerald Group Publishing Limited.

Hitt, M., Bierman, L., Shimizu, K., \& Kochhar, R. (2001). Direct and moderating effects of human capital on strategy and performance in professional service firms: A resource-based perspective. Academy of Management Journal, 44(1), 13-28.

Hitt, M., \& Duane, R. (2002). The essence of strategic leadership: Managing human and social capital. Journal of Leadership \& Organizational Studies, 9(1), 3-14.

Hung, R., Yang, B., \& Lien, B. (2010). Dynamic capability: Impact of process alignment and organizational learning culture on performance. Journal of World Business, 45(3), 285-294.

Ireland, R., \& Hitt, M. (2005). Achieving and maintaining strategic competitiveness in the 21st century: The role of strategic leadership. The Academy of Management Executive, 19(4), 63-77.

Jansen, J. J. P., Van Den Bosch, F. a. J., \& Volberda, H. W. (2005). Managing Potential and Realized Absorptive Capacity: How Do Organizational Antecedents Matter? Academy of Management Journal, 48(6), 999-1015.

Javalgi, R. G., Hall, K. D., \& Cavusgil, S. T. (2014). Corporate entrepreneurship, customer-oriented selling, absorptive capacity, and international sales performance in the international B2B setting: Conceptual framework and research propositions. International Business Review, 23(6), 1193-1202.

Kahiya, E. T., \& Dean, D. L. (2014). Export performance: multiple predictors and multiple measures approach. Asia Pacific Journal of Marketing and Logistics, 26(3), 378-407.

Katsikeas, C. S., \& Morgan, R. E. (1994). Differences in perceptions of exporting problems based on firm size and export market experience. European Journal of Marketing, 28(5), 17-35.

Katsikeas, C. S., Deng, S. L., \& Wortzel, L. H. (1997). Perceived export success factors of small and medium sized Canadian firms. Journal of International Marketing, 5(4), 53-72.

Kaynak, E., \& Kuan, W. K. (1993). Environment, strategy, structure, and performance in the context of export activity: an empirical study of Taiwanese manufacturing firms. Journal of Business Research, 27(1), 33-49.

Kostopoulos, K., Papalexandris, A., Papachroni, M., \& Ioannou, G. (2011). Absorptive capacity, innovation, and financial performance. Journal of Business Research, 64(12), 1335-1343.

Kotler, P. T., \& Keller, K. L. (2011). Marketing Management (14th ed.). Prentice Hall.

Lado, N., Martinez-Ros, E., \& Valenzuela, A. (2004). Identifying successful marketing strategies by export regional destination. International Marketing Review, 21(6), 573-597.

Lavie, D. (2006). The competitive advantage of interconnected firms: An extension of the resource-based view. Academy of Managment Review, 31(3), 638-658.

Leonidou, L. C., Katsikeas, C. S. \& Piercy, N. F. (1998). Identifying managerial influences on exporting: past research and future directions. Journal of International Marketing, 6(2), 74-102.

Liñán, F., \& Chen, Y. (2009). Development and cross-cultural application of a specific instrument to measure entrepreneurial intentions. Entrepreneurship Theory and Practice, 33(3), 593-617. 
Lu, J. W., \& Beamish, P. W. (2002). The Internationalization and Growth of SMEs. ASAC 2002, 86-96.

Lumpkin, G., \& Dess, G. (1996). Clarifying the entrepreneurial orientation construct and linking it to performance. Academy of Management Review, 21(1), 135-172.

Makadok, R. (2001). Toward a synthesis of the resource-based and dynamic-capability views of rent creation. Strategic Management Journal, 22(5), 387-401.

Marôco, J. (2011). Análise estatística com o SPSS Statistics (5a ed.). Pêro Pinheiro: ReportNumber, Lda.

Marques, A., \& Guedes, G. (2015). Innovation in "Low-Tech" Industries: Portuguese Footwear Industry. International Journal of Social, Behavioral, Educational, Economic, Business and Industrial Engineering, 9(9), 3020-3024.

Marr, B., \& Roos, G. (2005). A strategy perspective on intellectual capital. In B. Marr (ed.), Perspectives on intelectual capital (pp. 28-52). New York: Routledge.

Menon, A, Bharadwaj, S. G., Adidam, P. T., \& Edison, S. W. (1999). Antecedents and consequences of marketing strategy making: A model and a test. Journal of Marketing, 63(April), 18-40.

Moen, $\varnothing$. (1999). The relationship between firm size, competitive advantages export performance revisited. International Small Business Journal, 18(1), 53-72.

Möller, K. (2006). Role of competences in creating customer value: A value-creation logic approach. Industrial Marketing Management, 35(8), 913-924.

Molloy, J. C., Chadwick, C., Ployhart, R. E., \& Golden, S. J. (2011). Making Intangibles "Tangible" in Tests of Resource-Based Theory: A Multidisciplinary Construct Validation Approach. Journal of Management, 37(5), 1496-1518.

Monteiro, A., Soares, A. M., \& Rua, O. L. (forthcoming). Entrepreneurial orientation and export performance: the mediating effect of organisational resources and dynamic capabilities. Journal of International Business and Entrepreneurship Development.

Morgan, N. A., Kaleka, A., \& Katsikeas, C. S. (2004). Antecedents of Export Venture Performance: A Theoretical Model. Journal of Marketing, 68, 90-108.

Morgan, N., Vorhies, D. W., \& Schlegelmilch, B. B. (2006). Resourceperformance relationships in industrial export ventures: The role of resource inimitability and substitutability. Industrial Marketing Management, 35(5), 621-633.

Nag, R., Hambrick, D., \& Chen, M. (2007). What is strategic management, really? Inductive derivation of a consensus definition of the field. Strategic Management Journal, 955(October 2006), 935-955.

Newbert, S. (2007). Empirical research on the resource-based view of the firm: an assessment and suggestions for future research. Strategic Management Journal, 146, 121-146.

Nunnally, J. C. (1978). Psychometric theory. New York: McGraw-Hill.

Okpara, J. (2009). Entrepreneurial orientation and export performance: evidence from an emerging economy. International Review of Business Research Papers, 5(6), 195-211.

Pestana, M. H., \& Gageiro, J. N. (2008). Análise de Dados para Ciências Sociais - A complementaridade do SPSS (5a ed.). Lisboa: Edições Silabo.

Peteraf, M. (1993). The cornerstones of competitive advantage: A resource-based view. Strategic Management Journal, 14(3), 179-191.

Pfarrer, M. D., Pollock, T. G., \& Rindova, V. P. (2010). A tale of two assets: the effects of firm reputation and celebrity on earnings surprises and investors' reactions. Academy of Management Journal, 53(5), 1131-1152.

Piercy, N., Kaleka, A., \& Katsikeas, C. (1998). Sources of competitive advantage in high performing exporting companies. Journal of World Business, 33(4), 378-393.

Porter, M. (1980). Competitive Strategy. New York: Free Press.
Porter, M. (1991). Towards a dynamic theory of strategy. Strategic Management Journal, 12(S2), 95-117.

Porter, M., \& Millar, V. (1985). How information gives you competitive advantage. Harvard Business Review, 63(4), 149-160.

Porter, M., \& Montgomery, C. A. (1998). Estratégia: a busca da vantagem competitiva. Rio de Janeiro: Campus.

Reinartz, W., Haenlein, M., \& Henseler, J. (2009). An empirical comparison of the efficacy of covariance-based and variance-based SEM. International Journal of Research in Marketing, 26(4), 332-344.

Shamsie, J. (2003). The context of dominance: An industry-driven framework for exploiting reputation. Strategic Management Journal, 24(3), 199-215.

Sousa, C. M. P., Martínez-López, F. J. \& Coelho, F. (2008). The determinants of export performance: a review of the research in the literatures between 1998 and 2005. International Journal of Management Reviews, 10(4), 343-374.

Teece, D. J. (2007). Explicating dynamic capabilities: the nature and microfoundations of (sustainable) enterprise performance. Strategic Management Journal, 1350, 1319-1350.

Teece, D. J., Pisano, G., \& Shuen, A. (1997). Dynamic capabilities and strategic management. Strategic Management Journal, 18(7), 509-533.

Tzokas, N., Kim, Y. A., Akbar, H., \& Al-Dajani, H. (2015). Absorptive capacity and performance: The role of customer relationship and technological capabilities in high-tech SMEs. Industrial Marketing Management, 47, 134-142.

Ursic, M. L., \& Czinkota, M. R. (1984). An experience curve explanation of export expansion. Journal of Business Research, 12, 159-168.

Wang, C., \& Ahmed, P. K. (2007). Dynamic capabilities: A review and research agenda. International Journal of Management Reviews, 9(1), 31-51.

Westhead, P., Wright, M., \& Ucbasaran, D. (2001). The internationalization of new and small firms: A resource-based view. Journal of Business Venturing, 9026(99), 333-358.

Wiklund, J., \& Shepherd, D. (2005). Entrepreneurial orientation and small business performance: a configurational approach. Journal of Business Venturing, 20(1), 71-91.

Winter, S. G. (2000). The satisficing principle in capability learning. Strategic Management Journal, 21(10), 981-996.

Winter, S. G. (2003). Understanding dynamic capabilities. Strategic Management Journal, 24(10), 991-995.

Wolff, J. A., \& Pett, T. L. (2000). Internationalization of small firms: an examination of export competitive patterns, firm size, and export performance. Journal of Small Business Management, 38(2), 34-47.

Wood, V. R., \& Robertson, K. R. (1997). Strategic orientation and export success: an empirical study. International Marketing Review, 4(6), 424-444. Zahra, S., \& George, G. (2002). Absorptive capacity: A review, reconceptualization, and extension. Academy of Management Review, 27(2), 185-203.

Zahra, S., \& Hayton, J. (2008). The effect of international venturing on firm performance: The moderating influence of absorptive capacity. Journal of Business Venturing, 23(2), 195-220.

Received: 12 January 2017

Revisions required: 17 September 2017

Accepted: 8 January 2018 